Vegetalika. 2017. 6(3): 37-49

\title{
Pengaruh Pengurangan Jumlah Cabang dan Jumlah Buah terhadap Pertumbuhan dan Hasil Tomat (Solanum Lycopersicum L.)
}

\section{The Effect of Pruning and Thinning on the Growth and Yield of Tomato (Solanum Lycopersicum L.)}

\author{
Risda Hapsari ${ }^{1)}$, Didik Indradewa ${ }^{\left.2^{*}\right)}$, Erlina Ambarwati ${ }^{2)}$ \\ 1) Program Studi Agronomi, Fakultas Pertanian, Universitas Gadjah Mada \\ 2) Departemen Budidaya Pertanian, Fakultas Pertanian, Universitas Gadjah Mada \\ *) Penulis untuk korespodensi E-mail: didikindradewa54@yahoo.com
}

\begin{abstract}
'Servo' is high yielding variety, but the fruit weight lower than consumer preference. The researched was aimed to understand the effects of branch number on plant growth, branch and fruit number on yield components and fruit yield; and to obtain best branch and fruit number producing maximal yield and fruit size. The researched was conducted in field and arranged in a factorial $3 \times 3+1$ randomized complete block design with three blocks as replications. Branch number, as first factor, was maintained number of one, two, and up to three branches. Fruit number, as second factor, was maintained a number of 10, 15, and up to 20 fruits. The control treatment was growed naturally. Data were analyzed using analysis of variance. Post hoc analysis used were Tukey's Honest Significant Difference with significance level of 5\%. Results showed that reduction branch number didn't affect plant growth. Reduction fruit number, however, increased tomato yield components and reduction fruit number down to 4 fruit sets increased 'Servo' fruit weight up to 93,81 g.
\end{abstract}

Key words: branch number, fruit number, pruning, thinning, tomat

\section{INTISARI}

Tomat 'Servo' merupakan varietas tomat unggul, tetapi memiliki bobot buah yang tidak sesuai dengan permintaan konsumen. Penelitian bertujuan untuk mengetahui pengaruh jumlah cabang terhadap pertumbuhan tanaman, pengaruh jumlah cabang dan jumlah buah terhadap komponen hasil dan hasil buah tomat dan mendapatkan jumlah cabang dan jumlah buah yang memberikan hasil dan ukuran buah maksimal. Penelitian lapangan dilakukan dengan rancangan faktorial $3 \times 3+1$. Faktor pertama jumlah cabang yang dipelihara terdiri dari tiga aras : 1 cabang, 2 cabang dan 3 cabang. Faktor ke dua jumlah buah yang dipelihara terdiri dari tiga aras : 20 buah, 15 buah dan 10 buah. Kontrol dibiarkan tumbuh alami. Tata letak acak kelompok dengan tiga blok sebagai ulangan. Data yang diperoleh dianalisis varian dengan taraf kepercayaan yang digunakan yaitu 95\% untuk menyatakan ada perbedaan yang signifikan. Apabila perlakuan menunjukkan perbedaan yang nyata, dilanjutkan dengan perbandingan antar perlakuan dengan uji Tukey (HSD) pada taraf 5\%. Hasil penelitian memberikan informasi pengurangan jumlah cabang memberikan pengaruh yang sama terhadap pertumbuhan tanaman; pengurangan 
jumlah buah dapat meningkatkan komponen hasil buah tomat; pengurangan jumlah buah menjadi 4 buah per tandan dapat meningkatkan bobot buah tomat 'Servo' hingga 93,81 g.

Kata kunci: jumlah buah, jumlah cabang, pemangkasan, penjarangan, tomat

\section{PENDAHULUAN}

Tanaman tomat merupakan tanaman yang tergolong dalam kelompok sayuran. Kebutuhan pasar akan buah tomat terus meningkat, hal ini tidak lepas dari peranan tomat sebagai salah satu komoditas hortikultura yang sangat penting, yaitu terutama sebagai tanaman sayur. Bahkan, saat ini tomat tidak sekadar untuk sayuran tetapi sudah menjadi komoditas buah, tidak hanya untuk pasar dalam negeri akan tetapi juga untuk pasar ekspor (Kusuma dan Zuhro, 2015).

Masyarakat pada umumnya menyukai buah tomat yang warna kulitnya merahterang, kekerasan buah sedang (110-130 mm/50 g/10 det), bentuk buah agak lonjong, ukuran buah agak besar, rasa buah manis (4,25-5\%), tidak masam (kadar total asam (0,34-0,37\%), banyak mengandung air buah (kandungan air 92-93\%), dan buahnya renyah (Purwati, 2007). Kendala yang sering dihadapi petani dalam memenuhi peluang pasar swalayan dan ekspor terletak pada ketidaksesuaian antara kualitas yang dibutuhkan pasar dengan kualitas produk yang dihasilkan. Upaya yang dapat dilakukan untuk meningkatkan kualitas tanaman agar buah sesuai dengan permintaan pasar adalah dengan menggunakan varietas unggul dan memperhatikan teknik budidaya tanaman. Salah satu varietas tomat dataran rendah yang memiliki keunggulan produksi tinggi dan tahan terhadap gemini virus adalah varietas Servo. Selain itu, tomat 'Servo' memiliki buah keras dimana konsumen juga lebih menyukai tomat berkulit keras karena dapat disimpan lebih lama.

Sesuai dengan deskripsi varietas, ukuran buah yang dihasilkan 'Servo' termasuk dalam kelas C (<100 g). Namun, ukuran buah tomat yang disukai konsumen adalah ukuran buah yang agak besar, yaitu buah yang memiliki volume $80-90 \mathrm{~cm}^{3}$ atau setara dengan bobot buah per butir yang termasuk dalam grade $B(100<B<150 \mathrm{~g})$ (Marpaung, 1997; Purwati, 2007 cit. Ambarwati et al. 2012). Oleh karena itu, perlu dilakukan upaya untuk meningkatkan bobot buah agar ukuran buah sesuai dengan permintaan pasar.

Pemangkasan dan penjarangan buah merupakan salah satu upaya untuk mengoptimalkan kualitas buah. Biasanya petani hanya memihara dua cabang utama yang 
Risda Hapsari et al., / Vegetalika. 2017. 6(3): 37-49

tumbuh pada batang utama. Tomat 'Servo' merupakan salah satu varietas tomat yang memiliki tiga cabang per tanaman. Oleh karena itu, perlu dilakukan pengaturan jumlah cabang pada tomat 'Servo' agar diperoleh jumlah cabang dan luas daun yang optimal sebagai sumber untuk mengisi lubuk buah yang tersedia. Selain itu, jumlah buah pada tanaman tomat perlu diatur agar diperoleh lubuk penampung asimilat berupa jumlah buah yang optimal dengan ukuran yang sesuai permintaan pasar. Tujuan penelitian adalah untuk mengetahui pengaruh jumlah cabang terhadap pertumbuhan tomat; mengetahui pengaruh jumlah cabang dan jumlah buah terhadap komponen hasil dan hasil buah tomat; dan mendapatkan jumlah cabang dan jumlah buah yang memberikan hasil dan ukuran buah maksimal.

\section{BAHAN DAN METODE}

Bahan yang digunakan di lapangan adalah adalah benih tomat 'Servo', pupuk kompos, pupuk NPK Phonska, polibag diameter $45 \mathrm{~cm}$. Bahan yang digunakan di laboratorium adalah larutan IKI 0,001 N; aquades; dan amilum. Alat yang digunakan di lapangan adalah cangkul, rafia, alat tulis, gunting, ajir, meteran, luxmeter, termohigrometer, dan jangka sorong. Alat yang digunakan di laboratorium adalah neraca digital, oven, refraktometer, buret, gelas beaker, pipet tetes, erlenmeyer, penyaring, pisau, mortar, pH meter, dan jangka sorong.

Penelitian dilaksanakan pada bulan April sampai bulan Juli 2016. Penelitian ini dilaksanakan di lahan kas Desa Banguntapan, Bantul, Yogyakarta. Lokasi penelitian bertopografi dataran rendah dengan ketinggian \pm 113 meter di atas permukaan laut dan jenis tanah Regosol. Pengamatan di laboratorium dilaksanakan di sublaboratorium Manajemen Produksi dan sublaboratorium Hortikultura, Departemen Budidaya Pertanian, Universitas Gadjah Mada, Yogyakarta.

Penelitian lapangan dilakukan dengan rancangan faktorial $3 \times 3+1$. Faktor pertama jumlah cabang yang dipelihara terdiri dari tiga aras 1 cabang, 2 cabang dan 3 cabang. Faktor kedua jumlah buah yang dipelihara terdiri dari tiga aras : 20 buah, 15 buah dan 10 buah.. Kontrol dibiarkan tumbuh alami. Tata letak acak kelompok dengan tiga blok sebagai ulangan.

Variabel yang diamati adalah tinggi tanaman, diameter batang, panjang buah, diameter buah, bobot buah per tanaman, bobot buah per butir, ketebalan daging buah, 
ketebalan sekat, jumlah rongga buah, padatan terlarut total, vitamin $\mathrm{C}$, dan $\mathrm{pH}$ buah. Data yang diperoleh dianalisis varian dengan taraf kepercayaan yang digunakan yaitu 95\% untuk menyatakan ada perbedaan yang signifikan. Apabila perlakuan menunjukkan perbedaan yang nyata, dilanjutkan dengan perbandingan antar perlakuan dengan uji Tukey (HSD) pada taraf 5\%.

\section{HASIL DAN PEMBAHASAN}

Tinggi tanaman merupakan hasil pertumbuhan dan perkembangan tanaman. Pertambahan tinggi tanaman merupakan bentuk peningkatan pembelahan sel-sel akibat adanya translokasi asimilat yang meningkat (Mangera, 2013).

Tabel 1. Tinggi tanaman $(\mathrm{cm})$ tomat umur 8 minggu

\begin{tabular}{ccccc}
\hline \multirow{2}{*}{ Jumlah Buah } & \multicolumn{3}{c}{ Jumlah Cabang } & \multirow{2}{*}{ Rerata } \\
\cline { 2 - 4 } & 1 & 2 & 3 & $125,06 \mathrm{a}$ \\
15 & 120,22 & 125,69 & 129,26 & $124,69 \mathrm{a}$ \\
10 & 120,67 & 128,63 & 124,76 & $126,75 \mathrm{a}$ \\
\hline Rerata & 122,24 & 125,88 & 132,12 & $125,5(-)$ \\
\hline Kontrol & $121,04 \mathrm{p}$ & $126,73 \mathrm{p}$ & $128,71 \mathrm{p}$ & $126,14 \mathrm{~ns}$ \\
\hline
\end{tabular}

Keterangan: Angka-angka yang diikuti oleh huruf yang sama menandakan tidak terdapat beda nyata menurut uji HSD pada taraf $5 \%$. (-) Menunjukkan tidak ada interaksi. (ns) Tidak terdapat beda nyata antara kontrol dengan perlakuan menurut uji kontras

Berdasarkan Tabel 1. diketahui bahwa perlakuan berpengaruh tidak signifikan, tidak terdapat interaksi antara jumlah cabang dan buah terhadap tinggi tanaman tomat umur 8 minggu. Tanaman dengan jumlah cabang antara satu sampai tiga mempunyai tinggi tanaman yang sama. Tanaman yang dipelihara antara 10 hingga 20 buah per tanaman tidak mempengaruhi tinggi secara signifikan. Perkembangan buah selalu mengarah menjauh dari pangkal buah yaitu menuju ke ujung dan dapat diamati dengan mengukur panjang buah (Nurrochman et al. 2013). 
Risda Hapsari et al., / Vegetalika. 2017. 6(3): 37-49

Tabel 2. Panjang buah $(\mathrm{cm})$ pada perlakuan jumlah cabang dan jumlah buah

\begin{tabular}{ccccc}
\hline \multirow{2}{*}{ Jumlah Buah } & \multicolumn{3}{c}{ Jumlah Cabang } & \multirow{2}{*}{ Rerata } \\
\cline { 2 - 4 } & 1 & 2 & 3 & $4,99 \mathrm{~b}$ \\
20 & 4,89 & 4,94 & 5,15 & $5,20 \mathrm{ab}$ \\
15 & 5,22 & 5,22 & 5,16 & $5,29 \mathrm{a}$ \\
\hline 10 & 5,48 & 5,1 & 5,29 & $5,16(-)$ \\
\hline Rerata & $5,20 \mathrm{p}$ & $5,09 \mathrm{p}$ & $5,20 \mathrm{p}$ & $4,54^{*}$ \\
\hline Kontrol & \multicolumn{4}{c}{} \\
\hline
\end{tabular}

Keterangan: Angka-angka yang diikuti oleh huruf yang sama menandakan tidak terdapat beda nyata menurut uji HSD pada taraf $5 \%$. (-) Menunjukkan tidak ada interaksi. (*) Terdapat beda nyata antara kontrol dengan perlakuan menurut uji kontras

Tabel 2 menunjukkan panjang buah dipengaruhi perlakuan, tidak terdapat interaksi antara jumlah cabang dengan jumlah buah. Jumlah cabang memberikan pengaruh yang tidak signifikan terhadap panjang buah. Namun, jumlah buah memberikan pengaruh yang signifikan terhadap panjang buah. Gambar 1 menunjukkan bahwa jumlah buah memberikan hubungan linier negatif terhadap panjang buah dan ditunjukkan pada persamaan $Y=0,029 X+5,601$. Dimana semakin banyak jumlah buah yang dipelihara, maka ukuran buah akan semakin kecil. Penurunan ukuran buah dengan semakin banyaknya buah disebabkan oleh fotosintat yang dihasilkan tidak cukup untuk memenuhi kapasitas lubuk untuk meningkatkan ukuran buah (Zamzami et al. 2015).

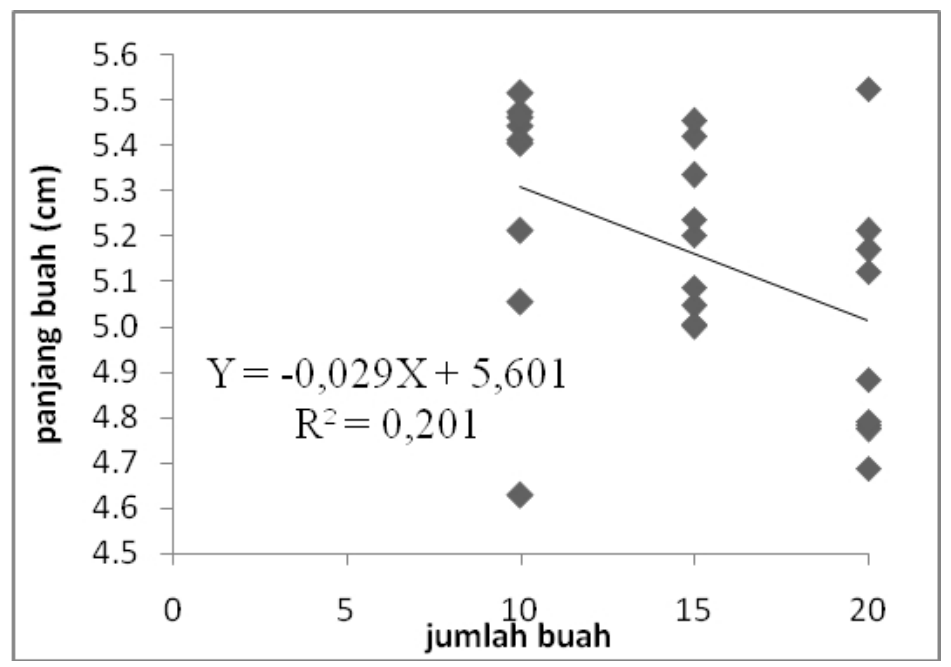

Gambar 1. Panjang buah pada perlakuan jumlah buah 
Tabel 3. Bobot buah per tanaman (g) pada perlakuan jumlah cabang dan jumlah buah

\begin{tabular}{ccccc}
\hline \multirow{2}{*}{ Jumlah Buah } & \multicolumn{3}{c}{ Jumlah Cabang } & \multirow{2}{*}{ Rerata } \\
\cline { 2 - 4 } & 1 & 2 & 3 & $1113,71 \mathrm{a}$ \\
\hline 20 & 1047,07 & 1088,94 & 1205,11 & $926,10 \mathrm{~b}$ \\
15 & 873,89 & 947,67 & 956,73 & $678,43 \mathrm{c}$ \\
\hline 10 & 667,89 & 649,35 & 718,07 & $906,08(-)$ \\
\hline Rerata & $862,95 \mathrm{p}$ & $895,32 \mathrm{p}$ & $959,97 \mathrm{p}$ & $1783,67^{*}$ \\
\hline Kontrol & & & & \\
\hline
\end{tabular}

Keterangan: Angka-angka yang diikuti oleh huruf yang sama menandakan tidak terdapat beda nyata menurut uji HSD pada taraf 5\%. (-) Menunjukkan tidak ada interaksi. $\left(^{*}\right)$ Terdapat beda nyata antara kontrol dengan perlakuan menurut uji kontras

Tabel 3 menunjukkan bobot buah per tanaman dipengaruhi perlakuan, tidak ada interaksi antara jumlah dengan jumlah buah. Jumlah cabang memberikan pengaruh yang tidak signifikan terhadap bobot buah per tanaman. Namun, jumlah buah memberikan pengaruh yang signifikan terhadap bobot buah per tanaman. Hubungan antara jumlah buah dengan bobot buah per tanaman memiliki kecenderungan linier negatif dengan persamaan $Y=43,52 X+253,1$ (Gambar 2). Semakin banyak jumlah buah, maka bobot buah per tanaman akan semakin tinggi.

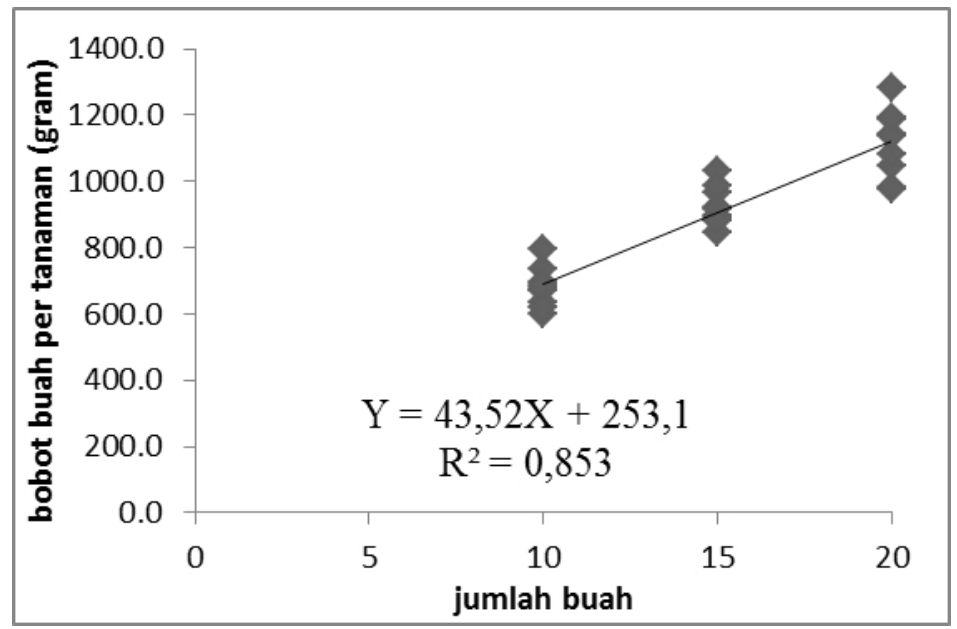

Gambar 2. Bobot buah per tanaman pada perlakuan jumlah buah

Penjarangan buah bertujuan supaya buah cukup mendapat ruang untuk tumbuh menjadi buah normal, sehingga akan didapat buah yang ukurannya relatif besar. Selain itu penjarangan buah juga mengurangi persaingan antar buah dalam mendapatkan asimilat yang digunakan untuk pertumbuhan buah (Nurrochman et al. 2013). Berdasarkan Tabel 4 diketahui bahwa bobot buah per butir dipengaruhi perlakuan, tidak ada interaksi antara jumlah cabang dengan jumlah buah. Jumlah cabang memberikan 
Risda Hapsari et al., / Vegetalika. 2017. 6(3): 37-49

pengaruh yang signifikan terhadap bobot buah per butir. Hubungan antara jumlah cabang dengan bobot buah per butir memiliki kecenderungan linier positif dengan persamaan $Y=$ 3,073X + 55,60 (Gambar 3a). Dimana semakin banyak jumlah cabang, maka bobot buah per butir akan akan semakin tinggi. Hal ini sesuai dengan penelitian yang dilakukan oleh Sumiati (1987) yang menunjukkan bahwa pemangkasan cabang pada tanaman tomat dengan meninggalkan tiga cabang utama meningkatkan bobot per buah dan bobot buah per tanaman. Isdamanto (2009) cit Majid (2012) menambahkan, semakin banyak hasil fotosintesis maka cadangan makanan semakin banyak pula dan dapat digunakan untuk menigkatkan berat buah.

Tabel 4. Bobot buah per butir (g) pada perlakuan jumlah cabang dan jumlah buah

\begin{tabular}{|c|c|c|c|c|}
\hline \multirow{2}{*}{ Jumlah Buah } & \multicolumn{3}{|c|}{ Jumlah Cabang } & \multirow{2}{*}{ Rerata } \\
\hline & 1 & 2 & 3 & \\
\hline 20 & 52,35 & 54,45 & 60,26 & $55,69 \mathrm{c}$ \\
\hline 15 & 58,26 & 63,18 & 63,78 & $61,74 \mathrm{~b}$ \\
\hline 10 & 66,79 & 64,94 & 71,81 & $67,84 \mathrm{a}$ \\
\hline Rerata & $59,13 q$ & $60,85 p q$ & $65,28 p$ & $61,76(-)$ \\
\hline Kontrol & & & & $45,95^{*}$ \\
\hline
\end{tabular}

Keterangan: Angka-angka yang diikuti oleh huruf yang sama menandakan tidak terdapat beda nyata menurut uji HSD pada taraf 5\%. (-) Menunjukkan tidak ada interaksi. (*) Terdapat beda nyata antara kontrol dengan perlakuan menurut uji kontras

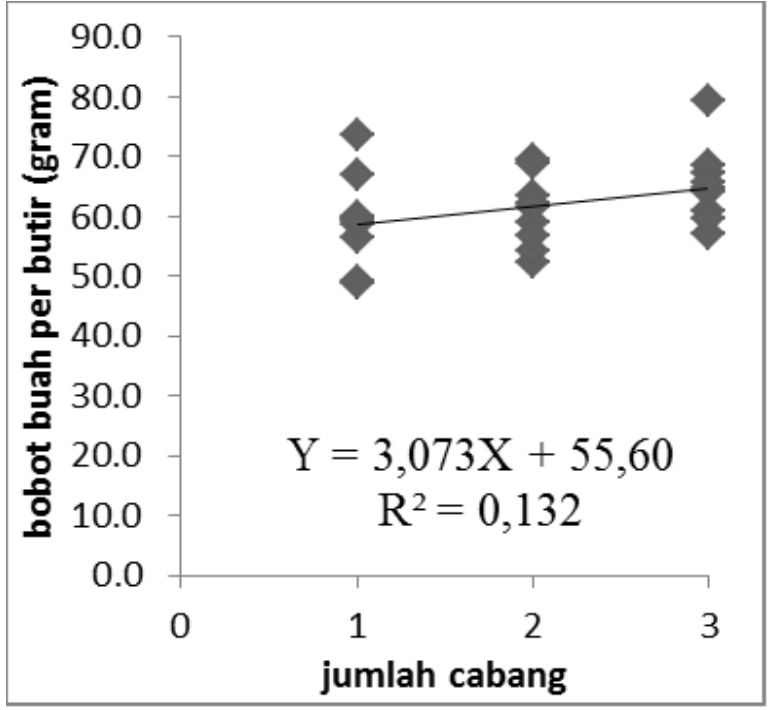

(a)

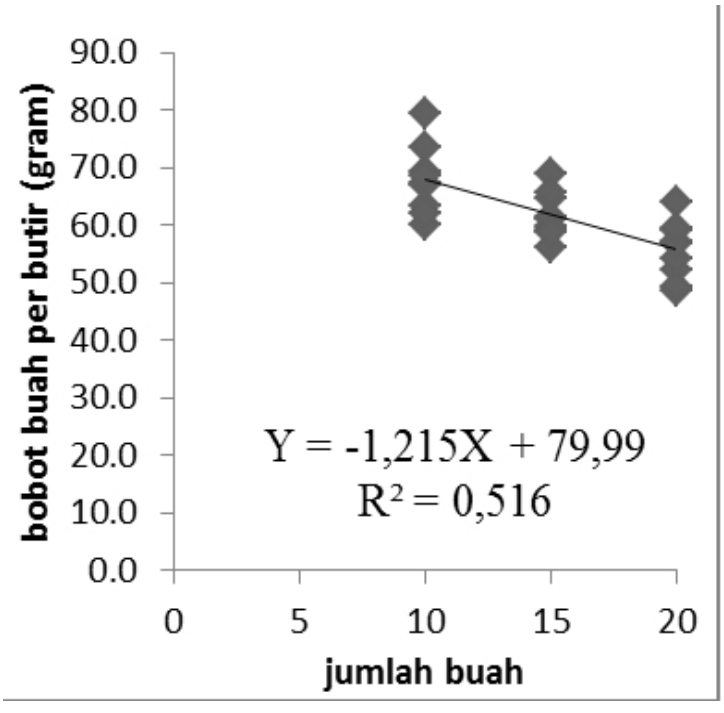

(b)

Gambar 3. Bobot buah per butir pada jumlah cabang (a) dan jumlah buah (b)

Jumlah buah yang dipelihara memberikan pengaruh yang signifikan terhadap bobot buah per butir. Hubungan antara jumlah buah dengan bobot buah per butir memiliki 
kecenderungan linier negatif dan ditunjukkan pada persamaan $Y=-1,215 X+79,99$ (Gambar 3b). Semakin sedikit buah yang ada, maka semakin besar volume buah dan bobot buah persatuan buah, hal ini disebabkan fotosintat yang dihasilkan oleh daun hanya terkonsentrasi kepada buah yang tidak terlalu banyak, sehingga bobot satuan buah akan meningkat (Zamzami et al. 2015). Gumelar et al (2014) menambahkan bahwa pengurangan buah dapat meningkatkan bobot buah per butir. Hal tersebut dimaksudkan mengurangi persaingan penggunaan fotosintat antara buah dan bunga, sehingga fotosintat dapat terkonsentrasi untuk perkembangan buah.

Tabel 5. Padatan terlarut total (Brix) pada perlakuan jumlah cabang dan jumlah buah

\begin{tabular}{ccccc}
\hline Jumlah Buah & \multicolumn{3}{c}{ Jumlah Cabang } & Rerata \\
\cline { 2 - 4 } & 4,66 & 4,74 & 4,83 & $4,74 a$ \\
20 & 4,76 & 4,85 & 4,77 & $4,79 \mathrm{a}$ \\
15 & 4,54 & 4,93 & 4,65 & $4,71 \mathrm{a}$ \\
\hline 10 & $4,65 \mathrm{p}$ & $4,84 \mathrm{p}$ & $4,75 \mathrm{p}$ & $4,75(-)$ \\
\hline Rerata & & & & $4,24^{*}$ \\
\hline Kontrol & & & & \\
\hline
\end{tabular}

Keterangan: Angka-angka yang diikuti oleh huruf yang sama menandakan tidak terdapat beda nyata menurut uji HSD pada taraf $5 \%$ (-) Menunjukkan tidak ada interaksi. (*) Terdapat beda nyata antara kontrol dengan perlakuan menurut uji kontras

Tabel 5 menunjukkan padatan terlarut total dipengaruhi perlakuan dan tidak terdapat interaksi antara jumlah cabang dengan jumlah buah. Jumlah cabang dan jumlah buah memberikan pengaruh yang tidak signifikan terhadap padatan total terlarut. Hal ini sesuai dengan penelitian yang menyatakan bahwa perlakuan pemangkasan ternyata juga tidak berpengaruh terhadap kadar gula pada buah (Koentjoro, 2012). Setyorini (2005) menjelaskan dengan pemakaian kultivar yang sama, maka akan memberikan hasil padatan gula terlarut yang sama karena kadar padatan gula terlarut lebih banyak dipengaruhi oleh kultivar tomat. Kisaran vitamin $\mathrm{C}$ pada buah tomat yang telah matang adalah 13 - $23 \mathrm{mg}$ per 100 gram buah (Jones, 1999). Kisaran vitamin C pada penelitian ini adalah 18,12 -22,65 mg per 100 gram buah. Hal ini menunjukkan bahwa vitamin C tersebut cenderung normal.

Berdasarkan Tabel 6 diketahui bahwa tidak ada interaksi antara jumlah cabang dengan jumlah buah, jumlah cabang dan jumlah buah memberikan pengaruh yang tidak signifikan terhadap vitamin C buah. Selain itu, vitamin C buah yang diberi perlakuan berbeda nyata apabila dibandingkan dengan kontrol. Dimana dalam hal ini vitamin $\mathrm{C}$ pada kontrol paling kecil dibandingkan dengan vitamin $\mathrm{C}$ buah yang diberi perlakuan. Hal 
Risda Hapsari et al., / Vegetalika. 2017. 6(3): 37-49

tersebut terjadi karena semakin banyak jumlah buah, maka asimilat yang diterima masingmasing buah akan semakin sedikit. Apabila jumlah asimilat yang diterima per buah sedikit, maka diduga asimilat yang diubah menjadi asam askorbat akan semakin sedikit sehingga vitamin C pada buah akan semakin rendah.

Tabel 6. Vitamin $\mathrm{C}$ buah pada perlakuan jumlah cabang dan jumlah buah

\begin{tabular}{ccccc}
\hline \multirow{2}{*}{ Jumlah Buah } & \multicolumn{3}{c}{ Jumlah Cabang } & Rerata \\
\cline { 2 - 4 } & 1 & 2 & 3 & $22,65 \mathrm{a}$ \\
\hline 20 & 23,55 & 23,47 & 20,92 & $21,74 \mathrm{a}$ \\
15 & 23,47 & 20,92 & 20,83 & $21,60 \mathrm{a}$ \\
\hline 10 & 21,74 & 21,41 & 21,64 & $21,99(-)$ \\
\hline Rerata & $22,92 \mathrm{p}$ & $21,93 \mathrm{p}$ & $21,13 \mathrm{p}$ & $18,12^{*}$ \\
\hline Kontrol & & & &
\end{tabular}

Keterangan: Angka-angka yang diikuti oleh huruf yang sama menandakan tidak terdapat beda nyata menurut uji HSD pada taraf 5\%. (-) Menunjukkan tidak ada interaksi. (*) Terdapat beda nyata antara kontrol dengan perlakuan menurut uji kontras

Keadaan lingkungan merupakan salah satu faktor yang dapat mempengaruhi pertumbuhan dan perkembangan tanaman. Tomat 'Servo' pada penelitian ini mengalami perubahan waktu berbunga dibandingkan deskripsi varietas, yaitu 15 hari lebih cepat. Hal ini menunjukkan bahwa tanaman lebih cepat memasuki fase generatif. Peralihan dari fase vegetatif ke fase generatif sebagian ditentukan oleh faktor genotipe dan sebagian lagi ditentukan oleh faktor luar seperti suhu, cahaya, dan kelembaban. Suhu lokasi penelitian berkisar $28-33^{\circ} \mathrm{C}$. Suhu ideal untuk pertumbuhan tomat adalah $18-25^{\circ} \mathrm{C}$. Wiryanta (2002) cit. Riskiyah (2014) menyatakan bahwa suhu harian yang melebihi batas optimum pada tanaman dapat mempercepat terjadinya pembungaan.

Bobot buah per tanaman yang dapat dicapai pada tanaman kontrol adalah 1,78 kg. Hasil tersebut lebih rendah dibandingkan dengan deskripsi varietas yang menyebutkan produksi tomat 'Servo' terendah yang dapat dicapai per tanaman adalah 2,11 kg. Hal tersebut diduga terjadi karena tomat 'Servo' dapat menghasilkan buah hingga 53 buah per tanaman, tetapi pada penelitian ini buah yang dapat dihasilkan pada tanaman kontrol adalah 37 hingga 40 buah per tanaman. Salah satu faktor yang menyebabkan menurunnya jumlah buah per tanaman tersebut adalah faktor lingkungan, yaitu suhu. Suhu udara siang hari tertinggi pada saat penelitian adalah saat tanaman berumur dua minggu yaitu $45,7^{\circ} \mathrm{C}$, sedangkan kisaran suhu udara siang hari saat 4 hingga 8 minggu adalah $33^{\circ} \mathrm{C}$ hingga $39^{\circ} \mathrm{C}$. Menurut Fardhani et al. (2013), pembuahan akan gagal pada temperatur malam hari $13^{\circ} \mathrm{C}$ atau lebih rendah atau diatas $21^{\circ} \mathrm{C}$ sedangkan temperatur siang hari yang masih dapat ditolerir berkisar $25^{\circ} \mathrm{C}-30^{\circ} \mathrm{C}$. Kondisi ini tanaman cenderung 
menggugurkan daun maupun bunga untuk kelangsungan hidupnya sehingga jumlah buah yang dihasilkan tidak optimal (Riskiyah, 2014).

Perlakuan memberikan pengaruh yang sama terhadap pertumbuhan tanaman. Pengurangan jumlah cabang pada tomat 'Servo' memberikan pengaruh yang tidak signifikan terhadap pertumbuhan tanaman. Hal ini menunjukkan bahwa tanaman yang diberi perlakuan maupun tidak diberi perlakuan memiliki tinggi tanaman dan diameter batang yang relatif sama. Tomat 'Servo' merupakan tomat determinate dimana tipe pertumbuhannya terbatas, fase vegetatif berhenti setelah memasuki fase generatif dan pertumbuhannya diakhiri dengan tumbuhnya bunga. Waktu berbunga yang lebih cepat menyebabkan pertumbuhan tanaman berlangsung lebih lambat.

Tanaman kontrol pada penelitian ini mempunyai tiga cabang per tanaman dan buah yang dihasilkan per tanaman adalah 37 hingga 40 buah. Pengurangan jumlah buah menjadi empat buah per tandan dapat meningkatkan bobot buah per butir $\pm 47 \%$ dibandingkan dengan kontrol. Susanto et al. (2004) menyatakan bahwa persentase jumlah buah layak jual dari total buah yang terbentuk cenderung lebih tinggi pada tanaman yang diberi perlakuan pemangkasan cabang dan penjarangan bunga dibandingkan dengan tanaman kontrol. Hal tersebut diduga akibat persaingan antara buah dan organ vegetatif untuk memperoleh asimilat pada tanaman yang diberi perlakuan lebih kecil dibandingkan dengan tanaman kontrol sehingga buah yang terbentuk dapat berkembang lebih sempurna.

Bobot buah per butir dapat meningkat ketika dilakukan pengurangan jumlah buah. Hal tersebut dapat terjadi karena semakin sedikit jumlah buah per tanaman, asimilat yang diterima per buah akan semakin banyak. Asimilat tersebut digunakan untuk meningkatkan panjang buah. Jika karbohidrat yang diterima per buah banyak maka diduga zat pati yang diubah menjadi gula akan semakin tinggi dan gula yang diubah menjadi asam askorbat akan semakin tinggi sehingga memberikan rasa buah yang manis pada buah dan kadar vitamin $\mathrm{C}$ yang lebih tinggi.

Menurut Ambarwari (2009) cit. Fardhani et al. (2013), buah tomat yang berbentuk bulat mempunyai rasio panjang dengan diameter antara 1 sampai $1,2(1 \leq p: d \leq 1,2)$. Hasil penelitian menunjukkan bahwa rasio panjang dengan diameter tomat 'Servo' adalah 1,13. Hal tersebut menunjukkan bahwa pengurangan jumlah buah tidak mengubah bentuk buah. Namun, pengurangan jumlah buah dapat meningkatkan bobot buah per butir. Hasil penelitian menunjukkan pada tanaman yang dikurangi jumlah buahnya menjadi 10 buah 
Risda Hapsari et al., / Vegetalika. 2017. 6(3): 37-49

dengan empat buah per tandan dapat meningkatkan bobot buah mendekati grade $B$, yaitu 93,81 gram per butir. Menurut, Adijaya dan Yasa (2014), semakin banyak jumlah buah yang dijarangkan dalam satu tandan dapat menyebabkan peningkatan ukuran buah karena penjarangan buah mengurangi persaingan antar buah dalam mendapatkan asimilat yang digunakan untuk pertumbuhan buah, sehingga buah yang dihasilkan lebih besar dan bentuk buah lebih baik.

Hasil penelitian menunjukkan bahwa dengan perlakuan dipelihara 10 buah per tanaman bobot buah per butir rerata buah baru mencapai 67,84 gram dan bobot buah per butir maksimal yang dapat dihasilkan adalah 71,81 gram yaitu pada perlakuan tanaman yang dipelihara tiga cabang dengan 10 buah per tanaman. Pada deskripsi varietas Servo, bobot buah per butir yang dapat dihasilkan adalah 63,04 hingga 66,47 gram. Artinya, pengurangan buah hingga 10 buah per tanaman hanya dapat meningkatkan bobot sebesar \pm 5 gram dan bobot buah standar sedang seberat 100 sampai 150 gram per butir (grade B) tidak pernah dicapai oleh varietas Servo. Jadi, perlakuan jumlah cabang dan jumlah buah tidak dapat meningkatkan bobot buah per butir secara signifikan karena keterbatasan sumber dan lubuk pada tomat varietas Servo.

\section{KESIMPULAN}

1. Pengurangan jumlah cabang memberikan pengaruh yang sama terhadap pertumbuhan tanaman.

2. Pengurangan jumlah buah dapat meningkatkan komponen hasil buah tomat.

3. Pengurangan jumlah buah menjadi 4 buah per tandan dapat meningkatkan bobot buah tomat 'Servo' hingga 93,81 g.

\section{SARAN}

Sebaiknya jumlah tandan per tanaman dikurangi dan jumlah buah per tandan dijarangkan menjadi empat buah agar hasil buah maksimal. 


\section{DAFTAR PUSTAKA}

Adijaya, I. N. dan I. M. R. Yasa. 2014. Pengaruh penjarangan buah terhadap produktivitas dan kualitas buah salak gula pasir pada panen raya. Prosiding Seminar Nasional “Inovasi Teknologi Pertanian Spesifik Lokasi: 445-451.

Ambarwati, E., G. A. P. Maya, S. Trisnowati, dan R. H. Murti. 2012. Mutu buah tomat dua galur harapan keturunan 'GM3' dengan 'Gondol Putih'. Prosiding Seminar Nasional Hasil Penelitian Pertanian.

Fardhani, A. E. Ambarwati, S. Trisnowati, dan R. H. Murti. 2013. Potensi hasil, mutu dan daya simpan buah enam galur mutan harapan tomat (Solanum lycopersicum L.). Vegetalika. 2: 88-100.

Gumelar, R. M. R., S. H. Sutjahjo, S. Marwiyah, dan A. Nindita. 2014. Karakterisasi dan respon pemangkasan tunas air terhadap produksi serta kualitas buah genotipe tomat lokal. Jurnal Hortikultura Indonesia. 5:73-83.

Jones, J. B. 1999. Tomato plant culture: in the field, greenhouse, and home garden. CRC Press, London.

Koentjoro, Y. 2012. Efektifitas model pemangkasan dan pemberian pupuk majemuk terhadap tanaman melon (Cucumis melo L.). Berkala Ilmiah Agroteknologi Plumula. 1: 9-17.

Kusuma, A. H. dan M. U. Zuhro. 2015. Pengaruh varietas dan ketebalan mulsa jerami padi pada pertumbuhan dan hasil tanaman tomat (Lycopersicum esculentum Mill). Agrotechbiz. 2: 1-20.

Majid, S.I., 2012. Pengaruh pemangkasan terhadap pertumbuhan dan hasil beberapa varietas tomat. <https://digilib.uns.ac.id/dokumen/detail/26472/PengaruhPemangkasan-Terhadap-Pertumbuhan-Dan-Hasil-Beberapa-Varietas-TomatLycopersicum-Esculentum-Mill > Diakses 18 Oktober 2016.

Mangera, Y., 2013. Analisis pertumbuhan tanaman gandum pada beberapa kerapatan tanaman dan imbangan pupuk nitrogen anorganik dan nitrogen kompos.<ejournal.unmus.ac.id/index.php/agricola/article/download/122/84> Diakses 19 Oktober 2016.

Nurrochman, S.Trisnowati, dan S. Muhartini. 2013. Pengaruh Pupuk Kalium Klorida dan Umur Penjarangan Buah terhadap Hasil dan Mutu Salak (Salacca zalacca (Gaertn.) Voss) 'Pondoh Super'. <https://jurnal.ugm.ac.id/index.php/jbp/article/view/1618> Diakses 9 November 2016.

Purwati. 2007. Varietas unggul harapan hibrida (F1) dari BALITSA. $<$ http://hortikultura.litbang.pertanian.go.id//PTEK/Purwati_tomat.pdf>. Diakses 15 Januari 2017.

Riskiyah, J. 2014. Uji Volume Air Pada Berbagai Varietas Tanaman Tomat (Lycopersicum esculentum Mill). <http://jom.unri.ac.id/index.php/JOMFAPERTA/article/view/2651> Diakses 10 Oktober 2016. 
Risda Hapsari et al., / Vegetalika. 2017. 6(3): 37-49

Sumiati, E. 1987. Pengaruh pemangkasan cabang terhadap hasil dan kualitas tomat kultivar Dondol dan Intan. Buletin Penelitian Hortikultura. 15: 49.54.

Susanto, S. dan E. M. Pribadi. 2004. Pengaruh pemangkasan cabang dan penjarangan bunga jantan terhadap pertumbuhan dan produksi Gherkin dengan budidaya hidroponik. Buletin Agronom. 32: 1-5.

Zamzami, M. Nawawi dan N. Aini. 2015. Pengaruh jumlah tanaman per polibag dan pemangkasan terhadap pertumbuhan dan hasil tanaman mentimun Kyuri (Cucumis sativus L.). Jurnal Produksi Tanaman. 3: 113 - 119. 